\title{
Rendimiento y respuesta de variedades de soya a mosca blanca Bemisia tabaci (Genn.) en tres fechas de siembra*
}

\section{Yield and response of soybean varieties to whitefly Bemisia tabaci (Genn.) in three planting dates}

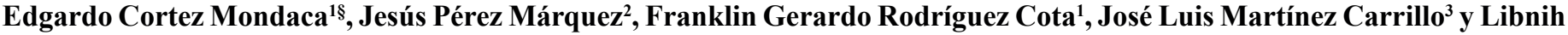 \\ Cervantes Cárdenas ${ }^{1}$ \\ ${ }^{1}$ Campo Experimental Valle del Fuerte-INIFAP. Carretera Internacional km 1609, C. P. 81110. Juan José Ríos, Guasave, Sinaloa. ${ }^{2}$ CEVACU- INIFAP-Carretera Culiacán- \\ Eldorado km 17.5, C. P. 80000 .Culiacán, Sinaloa. ${ }^{3}$ Instituto Tecnológico de Sonora. 5 de febrero 818 sur. C. P. 85000 , Cd. Obregón, Sonora. ${ }^{8}$ Autor para correspondencia: \\ cortez.edgardo@inifap.gob.mx.
}

\section{Resumen}

Los estudios de fechas de siembra son importantes para ayudar a conocer la adaptación, comportamiento y plasticidad de nuevos materiales vegetales en un ambiente determinado, bajo diferentes condiciones de manejo y presión de factores abióticos, y bióticos. Durante el ciclo primavera-verano 2009-2009 se evaluó el comportamiento agronómico, fenología y respuesta a mosca blanca de 12 genotipos de soya en tres fechas de siembra en el norte de Sinaloa, México. Los tratamientos incluyeron seis variedades de soya no evaluadas en la región: AG 5605, AG 5903, AG 5905, AG 6301, AG 6702 y DB 6451; tres variedades comerciales: Cajéme, Héctor (Nainari) y Balbuena S-94; la variedad Hutcheson altamente preferida por mosca blanca y dos líneas avanzadas del Instituto Nacional de Investigaciones Forestales Agrícolas y Pecuarias candidatas a nuevas variedades de soya para el noroeste de México: Cu04-139 y Cu04-238. Las mejores combinaciones genotipo por fecha de siembra con relación al rendimiento de grano fueron: Cu04-139 con 2496.1 y $2442.9 \mathrm{~kg} \mathrm{ha}^{-1}$ en la primera y segunda fecha de siembra, Balbuena S-94; AG 6702 y AG 6301 con 2 360.8; 2261.3 y $2247.5 \mathrm{~kg} \mathrm{ha}^{-1}$ en primera, tercera y segunda fecha de siembra respectivamente. Los genotipos consistentemente más preferidos por adultos de mosca blanca y mayormente

\section{Abstract}

Planting date studies are important to help understand adaptation, behavior and plasticity of new plant materials in a given environment, under different management conditions and pressure of abiotic and biotic factors. During the spring-summer 2009-2009 was evaluated the agronomic behavior, phenology and response to whitefly of 12 soybean genotypes on three sowing dates in northern Sinaloa, Mexico. Treatments included six soybean varieties not evaluated in the region: AG 5605, AG 5903, AG 5905, AG 6301, AG 6702 and DB 6451; three commercial varieties Cajeme, Hector (Nainari) and Balbuena S-94; the variety Hutcheson highly preferred by white fly and two advanced lines from the National Research Institute for Forestry, Agriculture and Livestock candidates to new soybean varieties for the Northwest of Mexico: $\mathrm{Cu}$ 04-139 and $\mathrm{Cu}$ 04-238. The best genotype combinations by planting date in relation to grain yield were: CU04-139 with 2496.1 and $2442.9 \mathrm{~kg} \mathrm{ha}^{-1}$ in the first and second planting date, Balbuena S-94; AG 6702 and AG 6301 with 2 360.8; 2261.3 and 2 $247.5 \mathrm{~kg} \mathrm{ha}^{-1}$ in the first, third and second planting date respectively. The most preferred genotypes by adults and pupa of whitefly are Hutcheson, DB 6451, AG 5905 and $A G$ 6301. In contrast the less preferred varieties and

\footnotetext{
* Recibido: marzo de 2013

Aceptado: agosto de 2013
} 
infestados por sus inmaduros fueron las variedades Hutcheson, DB 6451, AG 5905 y AG 6301. En contraparte las variedades menos preferidas y menos infestadas fueron Héctor, Cu04-238, S-94, Cajéme y AG 5903. La tercera fecha de siembra mostró la mayor abundancia de mosca blanca.

Palabras clave: fenología, genotipos, mosca blanca, preferencia, rendimiento, resistencia vegetal.

\section{Introducción}

El Comité Calificador Regional de Variedades y Plantas (CCRVP) es el organismo oficial a través del cual se evalúan las nuevas variedades que se pretenden introducir a determinada región, para la autorización de la siembra y explotación comercial en México, para lo cual, se requiere contar con información específica de comportamiento bajo las condiciones del ambiente en que se pretenden establecer, después de reproducciones sucesivas (SNICS, 2011) por mínimo tres ciclos homólogos.

En los últimos años se han introducido a la región variedades de soya de diversas compañías. Algunas han sido evaluadas por el CCRVP, de las cuales pocas presentan buena adaptación, sanidad y potencial de rendimiento, compitiendo con las variedades de mayor uso en la región (Cortez et al., 2005). Los estudios de fechas de siembra son importantes para ayudar a conocer mejor la adaptación, comportamiento y plasticidad de los nuevos materiales en un ambiente determinado bajo diferentes condiciones de manejo, ya que la fecha de siembra influye en el desarrollo de la planta y producción de grano, actúan sobre la planta condiciones climáticas que pueden favorecer o limitar sus funciones fisiológicas, o bien sobre organismos que pueden influir en la sanidad del cultivo (Flint y Gouveia, 2001; Baigorri, 2002).

Es importante utilizar variedades de soya resistentes a mosca blanca Bemisia tabaci (Genn.) (Hemiptera: Aleyrodidae), ya que en elevadas poblaciones que se presenta provoca siniestros parciales y totales de la producción (Martínez et al., 1998). El objetivo del estudio fue determinar el comportamiento agronómico: fenología, rendimiento y respuesta a mosca blanca de 12 genotipos de soya en tres fechas de siembra, bajo las condiciones ambientales de la región norte de Sinaloa. less infested were Hector, CU04-238, S-94, Cajeme and AG 5903. The third planting date showed the greatest abundance of whiteflies.

Key words: phenology, genotypes, whitefly, preference, preference, plant resistance.

\section{Introduction}

The Regional Examination Committee of Varieties and Plants (CCRVP) is the official agency through which are evaluated the new varieties that are intended to be introduced to certain region, for sowing authorization and commercial planting in Mexico, for which it is required to count specific information on behavior under environmental conditions in which is pretended to establish, after successive reproductions (SNICS, 2011) for at least three homologous cycles.

In recent years have been introduced to the region soybean varieties of different companies. Some have been evaluated by the CCRVP, from which few have a good adaptation, health and yield potential, competing with the most used varieties in the region (Cortez et al., 2005). Planting dates studies are important to help understand adaptation and plasticity behavior of new materials in a given environment under different management conditions, since planting date affects plant development and grain yield, acting on the plant weather conditions that may favor or limit their physiological functions or on bodies that can influence crop health (Flint and Gouveia, 2001; Baigorri, 2002).

It is important to use soybean varieties resistant to whitefly Bemisia tabaci (Genn.) (Hemiptera: Aleyrodidae), when high populations are present causes partial and total losses of production (Martínez et al., 1998). The objective of the study was to determine the agronomic behavior: phenology, yield and response to whitefly from 12 soybean genotypes in three planting dates under the environmental conditions of northern Sinaloa.

\section{Materials and methods}

The experiment was established on the premises of the Experimental Field Valle del Fuerte (CEVAF) from the National Institute for Forestry, Agriculture and Livestock 


\section{Materiales y métodos}

El experimento se estableció en las instalaciones del Campo Experimental Valle del Fuerte(CEVAF) del Instituto Nacional de Investigaciones Forestales Agrícolas y Pecuarias (INIFAP), en Juan José Ríos, Sinaloa, México, con coordenadas $25^{\circ} 45^{\prime}$ 36" latitud norte y $108^{\circ} 48^{\prime} 41^{\prime \prime}$ longitud oeste, altitud de 15 msnm, con clima cálido, seco estepario de tipo desértico, temperatura media anual de $25.0{ }^{\circ} \mathrm{C}$ y precipitación media en el año de $352 \mathrm{~mm}$ registrada principalmente en los meses de julio a septiembre (Ruíz et al., 2005).

\section{Tratamientos}

Se evaluaron 12 genotipos de soya durante el ciclo primavera-verano 2009-2009, seis variedades no evaluadas en la región norte de Sinaloa: AG 5605, AG 5903, AG 5905, AG 6301, AG 6702, DB 64-51; cuatro variedades comerciales: Cajéme, Héctor (Nainari) resistente a MB por elmecanismo de no preferencia, Balbuena S-94 y Hutcheson variedad altamente preferida por MB (Cortez et al., 2005) y dos líneas avanzadas de INIFAP candidatas a nuevas variedades de soya para el noroeste de México: Cu04-139 y Cu04-238; en tres fechas de siembra 19 de mayo; 05 de junio y 22 de junio.

\section{Variables agronómicas evaluadas en genotipos de soya}

Las variables estudiadas fueron: días a floración(R2), días a partir de la siembra hasta la aparición de una flor abierta en uno de los dos nudos superiores del tallo principal, con una hoja completamente desplegada; días a formación de grano (R5); días a madurez fisiológica (R8), cuando el cultivo ha alcanzado 95\% de madurez (Fehr et al., 1971); altura de planta, de la cicatriz del nudo cotiledonal hasta la yema terminal; altura de vainas basales; vainas por planta; peso de 100 semillas, rendimiento ajustado al 14\% de humedad y transformado a kilogramos por hectárea $(\mathrm{kg}$ $\left.\mathrm{ha}^{-1}\right)$. Al final los datos se sometieron a un ANOVA (SAS ${ }^{\circledR}$, 2001) de acuerdo al diseño experimental de parcelas divididas y las medias se compararon por Tukey con un alfa de 0.05 .

\section{Respuesta de los genotipos de soya a mosca blanca}

Se contabilizaron huevos, ninfas chicas (N1), ninfas grandes (N4) y adultos dos veces por semana por fecha de siembra, durante el periodo crítico de protección del cultivo, entre
(INIFAP) in Juan José Ríos, Sinaloa, Mexico, with coordinates $25^{\circ} 45^{\prime} 36^{\prime \prime} \mathrm{N}$ and $108^{\circ} 48^{\prime} 4^{\prime \prime} \mathrm{W}$, altitude of 15 masl, with warm climate, dry steppe desert type, average annual temperature of $25.0^{\circ} \mathrm{C}$ and average rainfall in the year of $352 \mathrm{~mm}$ recorded mainly in the months of July to September (Ruiz et al., 2005).

\section{Treatments}

12 soybean genotypes were evaluated during the springsummer cycle 2009-2009, six varieties non evaluated in northern Sinaloa: AG 5605, AG 5903, AG 5905, AG 6301, AG 6702, DB 64-51; four commercial varieties : Cajeme, Hector (Nainari) resistant to whitefly by the nonpreference mechanism, Balbuena S-94 and Hutcheson highly preferred variety by whitefly (Cortez et al., 2005) and two advanced lines from INIFAP candidates to new soybean varieties for the northwestern of Mexico: CU04139 and CU04-238; on three planting dates May 19, June 05 and June 22.

\section{Agronomic variables in soybean genotypes}

The variables studied were: days to flowering (R2), days from sowing to the appearance of an open flower at one of the two upper nodes of the main stem, with a fully unfolded leaf; days to seed formation (R5); days to physiological maturity (R8), when the crop has reached 95\% maturity (Fehr et al., 1971); plant height, from the scar of cotyledon junction to the terminal bud; basal pod height, pods per plant; weight of 100 seeds, yield adjusted to $14 \%$ moisture and converted to kilograms per hectare $\left(\mathrm{kg} \mathrm{ha}^{-1}\right)$. At the end data was subjected to ANOVA (SAS $\left.{ }^{\circledR}, 2001\right)$ according to the split plot experimental design and means were compared by Tukey with an alpha of 0.05 .

\section{Response of soybean genotypes to whiteflies}

Eggs, small nymphs (N1), large nymphs (N4) and adults were counted twice a week by planting date, during the critical period of crop protection, between 30 and 75 days after emergence (López, 1996a), phenological stage between stages R1 (beginning of flowering) and R5 (grain formation).

The plant is divided into three layers, apical or upper, middle and basal, according to the number of internodes; inspected 10 leaves from the fifth apical node (five leaves on five plants of the groove 2 and the same at groove 5, to account 
los 30 y 75 días después de la emergencia (López, 1996a), etapa fenológica comprendida entre los estados R1 (inicio de floración) y R5 (formación de grano).

La planta se dividió en tres estratos, apical o superior, medioy basal, de acuerdo al número de entrenudos; se inspeccionaron 10 hojas del quinto nudo apical (cinco hojas en cinco plantas del surco 2 y lo mismo en el surco 5, para contabilizar el número total de adultos, volteando con cuidado la hoja central del trifolio (modificado de Ellsworth et al., 1994). Las mismas hojas se recolectaron e introdujeron en una bolsa de papel estraza para inspeccionar en laboratorio el número de huevos y N1; al principio, se considero contabilizar el número total de individuos, pero si la incidencia era muy elevada (10 o más especímenes/hoja), se inspeccionarían los insectos presentes en 1 pulgada de diámetro, en el centro del foliolo central.

En las plantas donde se recolectaron las hojas parainspeccionar adultos, huevos e inmaduros jóvenes se recolectaron el mismo número de hojas del estrato medio, se introducirán en bolsas de papel estraza y sellevaban a laboratorio, para inspeccionar N4. Los datos de muestreo de adultos e inmaduros de MB se concentraron, para realizar el ANOVA $\left(\mathrm{SAS}^{\circledR}, 2010\right)$ de acuerdo a un diseño completamente aleatorio y determinar significancia entre tratamientos y separar medias por Tukey con un alfa de 0.05 .

\section{Diseño experimental}

El estudio se estableció en un diseño experimental de parcelas divididas con tres repeticiones, las parcelas grandes fueron las fechas de siembra y las parcelas chicas los genotipos. La unidad experimental constó de seis surcos de $6 \mathrm{~m}$ de largo, con una separación entre si de $0.8 \mathrm{~m}$ en donde los dos surcos centrales 3 y 4 de $5 \mathrm{~m}$ de longitud se utilizaron para la evaluación agronómica y los surcos 2 y 5 para la evaluación de incidencia de MB, los surcos 1 y 6 fueron los surcos orilleros.

\section{Datos agronómicos}

La siembra se realizó en húmedo, con una densidad de 20 semillas por metro lineal de surco, el terreno no se fertilizó. Durante el desarrollo del cultivo se realizaron las labores culturales sugeridas para este cultivo por el CEVAF (2003): preparación del terreno (dos rastreos), un cultivo, una escarda, tres riegos de auxilio, durante la estación de crecimiento del cultivo se registraron lluvias que acumularon $488.1 \mathrm{~mm}$ de agua $(24.4 \mathrm{~mm} ; 92.6 \mathrm{~mm} ; 154.3 \mathrm{~mm} ; 58.4 \mathrm{mmy} 158.4 \mathrm{~mm}$ en junio, julio, agosto, septiembre yoctubre respectivamente). Se the total number of adults, carefully turning the central leaf from the trefoil (modified from Ellsworth et al., 1994). The same leaves were collected and introduced into a brown paper bag to inspect the number of eggs in the laboratory and $\mathrm{N} 1$; at the beginning, was considered counting the total number of individuals, but if the incidence was very high (10 or more specimens / leaf), it would be inspected the insects present at 1 inch in diameter, in the center of the central leaflet.

In plants where leaves were collected to inspect adults, eggs and pupa were collected the same number of leaves from the middle stratum, introduced into brown paper bags and carried to the laboratory, to inspect N4. Data sampling of adults and pupa of whitefly were concentrated to perform ANOVA (SAS $\left.{ }^{\circledR}, 2010\right)$ according to a completely randomized design and determine significance between treatments and separate means through Tukey with an alpha of 0.05 .

\section{Experimental design}

The study was established in a split plot design with three replications, the large plots were planting dates and subplots the genotypes. The experimental unit consisted of six grooves of $6 \mathrm{~m}$ long, with a separation of $0.8 \mathrm{~m}$ where the two central rows 3 and 4 , of $5 \mathrm{~m}$ in long were used for agronomic evaluation and grooves 2 and 5 for evaluation of whitefly incidence, grooves 1 and 6 grooves were borders.

\section{Agronomic data}

Planting was made in wet, with a density of 20 seeds per linear meter of groove, the field was not fertilized. During crop development were made cultural work suggested for this crop by CEVAF (2003): site preparation (plowing), cultivation, weeding and three irrigations during crop development registered rainfalls that accumulated $488.1 \mathrm{~mm}$ (24.4 mm; $92.6 \mathrm{~mm} ; 154.3 \mathrm{~mm} ; 58.4 \mathrm{~mm}$ and $158.4 \mathrm{~mm}$ in June, July, August, September and October respectively). There were three insecticide applications, two against tarnished plant bug Lygus lineolaris (Palisot de Beauvois) (Hemiptera: Miridae) the first with the methamidophos insecticide at $1 \mathrm{~L} \mathrm{ha}^{-1}$ and the second with Malathion $1 \mathrm{~L}$ $\mathrm{ha}^{-1}$; a spraying against worms defoliating, velvet worm Anticarsia gemmatalis Hübner and cabbage looper Trichoplusia ni Hübner (Lepidoptera: Noctuidae) with insectisides Chlorpyrifos $1 \mathrm{~L} \mathrm{ha}^{-1}+$ Cyflutrina $0.4 \mathrm{~L} \mathrm{ha}^{-1}$, the spraying of insecticides were made in the three planting 
realizaron tres aplicaciones de insecticida, dos contra chinche ligus Lygus lineolaris (Palisot de Beauvois) (Hemiptera: Miridae) la primera con el insecticida Metamidofós a razón de $1 \mathrm{~L} \mathrm{ha}^{-1} \mathrm{y}$ la segunda con Malatión $1 \mathrm{~L} \mathrm{ha}^{-1}$; una aspersión contra gusanos defoliadores, gusano terciopelo Anticarsia gemmatalis Hübner y falso medidor Trichoplusia ni Hübner (Lepidoptera: Noctuidae) con los insecticidas Clorpirífos 1L ha $^{-1}+$ Cyflutrina $0.4 \mathrm{~L} \mathrm{ha}^{-1}$; las aspersiones de insecticidas se realizaron en las tres fechas de siembra; sin embargo, se observó mayor presencia de lepidópteros en las dos últimas fechas de siembra. Se realizó control de maleza mediante dos escardas y un deshierbe manual.

\section{Resultados y discusión}

\section{Variables agronómicas de los genotipos de soya}

Se observó diferencia significativa $(p<0.001)$ para las variables días a floración (R2); días a formación de grano (R5); días a madurez fisiológica (R7); altura de planta; y rendimiento, en ambos factores estudiados, genotipos y fechas de siembra, y su interacción, así como en peso de 100 semillas en ambos factores y altura de vainas basales entre genotipos, mientras que para el número de vainas por planta, se observó diferencia estadística significativa $(p<0.005)$ en ambos factores y su interacción; para altura de vainas basales entre fechas de siembra y su interacción con genotipos no se observó diferencia significativa, lo mismo que para peso de 100 semillas entre fechas de siembra. Sin embargo, los datos se consideran estándar y aceptables para genotipos comerciales de soya para el norte de Sinaloa, con excepción de la altura de vaina en la que los genotipos AG 5905 y AG 5605 mostraron una altura reducida(Cuadro 1) que en elmomento de lacosecha propicia la perdida de grano por no alcanzarse a trillar, además resultaron los de menor rendimiento, por debajo de $1.5 \mathrm{tha}^{-1}$.

Cabe señalar que los cultivares que no alcanzan las $2 \mathrm{t} \mathrm{ha}^{-1}$ difícilmente podrán ser competitivas en el mercado, lo que en esta evaluación alcanzaron Héctor, Balbuena S-94 y la Cu04-139, está última la de mayor rendimiento con diferencia altamente significativa con el resto de genotipos $(p<0.005)$; la línea Cu04-238 no alcanzó, por poco, las $2 \mathrm{t}$ ha $^{-1}$ pero se ubicó en el mismo grupo de medias que Héctor, Balbuena S-94 y AG 6702 (Cuadro 1). La segunda y tercer fecha de siembra (junio 05 y junio 22), se ubicaron dentro del primer grupo de significancia con un rendimiento medio de 1937.8 y $1864.9 \mathrm{~kg} \mathrm{ha}^{-1}$ respectivamente (Cuadro2). dates; however, there was higher presence of Lepidoptera in the last two planting dates. Weed control was performed by two hoeing and hand weeding.

\section{Results and discussion}

\section{Agronomic traits of soybean genotypes}

Significant difference was observed $(p<0.001)$ for variables days to flowering (R2), days to grain formation (R5), days to physiological maturity (R7), plant height, and yield, in both factors, genotypes and planting dates, and their interaction, as well as 100 seed weight in both factors and basal pod height between genotypes; while the number of pods per plant, had a significant statistical difference $(p<$ 0.005 ) in both factors and their interaction; for basal pod height between planting dates and their interaction with genotypes there was no significant difference, the same as for 100 seed weight between planting dates. However, the data is considered standard and acceptable for commercial soybean genotypes for northern Sinaloa, except for the pod height in which genotypes AG 5905 and AG 5605 showed a reduced height (Table 1) that at the time of harvest favors the loss of grain for not being able to thresh, besides were the lower yielding below $1.5 \mathrm{tha}^{-1}$.

It should be noted that cultivars that do not reach the $2 \mathrm{tha}^{-1} \mathrm{can}$ hardly be competitive in the market, which in this evaluation reached, Hector, Balbuena S-94 and CU04-139, the latter with the highest yield with highly significant difference with the rest of genotypes $(p<0.005)$; line Cu04-238 did not reach for some, the $2 \mathrm{t} \mathrm{ha}^{-1}$ but placed in the same group of means that Hector, Balbuena S-94 and AG 6702 (Table 1). The second and third planting date (June 05 and June 22), were placed in the first group of significance with an average yield of 1937.8 and $1864.9 \mathrm{~kg} \mathrm{ha}^{-1}$ respectively (Table2).

In Table 3, are observed the values of genotype-planting date interaction, the best combinations were: $\mathrm{Cu} 04-139$ with 2 496.1 and $2442.9 \mathrm{~kg} \mathrm{ha}^{-1}$ in the first and second planting date, followed by Balbuena S -94, AG 6702 and AG 6301 to $2360.8,2261.3$ and $2247.5 \mathrm{~kg} \mathrm{ha}^{-1}$ in the first, third and second planting date respectively.

The results suggest to consider extending the planting season in May and June, instead of the currently recommended from May 01 to 20; however later plantings to June 15 may 
Cuadro 1. Concentración de medias para diferentes características agronómicas de 12 genotipos de soya en tres fechas de siembra.

Table 1. Concentration of means for different agronomic traits from 12 soybean genotypes in three planting dates.

\begin{tabular}{|c|c|c|c|c|c|c|c|c|c|}
\hline \multirow[t]{2}{*}{ Genotipo } & \multicolumn{3}{|c|}{ Días a } & \multirow{2}{*}{$\begin{array}{c}\text { Altura de } \\
\text { Planta }(\mathrm{cm})\end{array}$} & \multirow{2}{*}{$\begin{array}{c}\text { Altura de } \\
\text { vainas }(\mathrm{cm})\end{array}$} & \multirow{2}{*}{$\begin{array}{l}\text { Vainas/ } \\
\text { plantas }\end{array}$} & \multirow{2}{*}{$\begin{array}{c}\text { Peso de } 100 \\
\text { sem. (gr) }\end{array}$} & \multirow[t]{2}{*}{ Rend. kg ha-1 } & \multirow{2}{*}{$\begin{array}{l}\text { Color } \\
\text { de flor }\end{array}$} \\
\hline & $\mathrm{R} 2$ & R5 & R7 & & & & & & \\
\hline $\mathrm{Cu} 04-139$ & 53 & 82 & 115 & 62.8 & 8.1 & 76.4 & 12.3 & $2381.1 \mathrm{a}$ & $\mathrm{M}$ \\
\hline Balbuena S-94 & 55 & 83 & 119 & 70.1 & 8.9 & 70.7 & 13 & $2054.4 \mathrm{~b}$ & M \\
\hline Héctor & 54 & 82 & 115 & 72.2 & 9.1 & 65 & 12.6 & $2031.8 \mathrm{~b}$ & M \\
\hline $\mathrm{Cu} 04-238$ & 54 & 81 & 115 & 76.3 & 9.4 & 70 & 12.9 & $1981.9 \mathrm{~b}$ & $\mathrm{M}$ \\
\hline AG 6702 & 55 & 85 & 122 & 47.7 & 7.6 & 56.8 & 10.7 & $1962.6 \mathrm{~b}$ & M \\
\hline AG 6301 & 53 & 83 & 116 & 44.7 & 6.2 & 61.7 & 11.3 & $1955.6 \mathrm{bc}$ & M \\
\hline hutcheson & 51 & 82 & 115 & 54.6 & 6.2 & 66.6 & 13.1 & $1839.3 \mathrm{bc}$ & $\mathrm{B}$ \\
\hline AG 5903 & 50 & 80 & 117 & 40.1 & 8.7 & 50.7 & 12.9 & $1690.7 \mathrm{~cd}$ & $\mathrm{~B}$ \\
\hline DB 6451 & 53 & 83 & 116 & 41.6 & 11.4 & 61.7 & 11.1 & $1566.8 \mathrm{de}$ & $\mathrm{B}$ \\
\hline Cajéme & 54 & 83 & 117 & 86.2 & 11.8 & 65.9 & 12 & $1530.0 \mathrm{de}$ & M \\
\hline AG 5905 & 52 & 81 & 116 & 44.2 & 5.8 & 56.3 & 12.4 & $1357.2 \mathrm{e}$ & $\mathrm{B}$ \\
\hline AG 5605 & 50 & 80 & 118 & 35.1 & 3.9 & 52 & 12.3 & $1074.0 \mathrm{f}$ & M \\
\hline Promedio & 53 & 82 & 117 & 56.3 & 7.3 & 62.8 & 12.2 & 1785.50 & \\
\hline
\end{tabular}

*Medias con la misma letra no difieren estadísticamente (Tukey 0.05). $\mathrm{M}=$ morado; $\mathrm{B}=$ blanco.

Cuadro 2. Concentración de medias para diferentes características agronómicas de 12 genotipos de soya en tres fechas de siembra.

Table 2. Concentration of means for different agronomic traits from 12 soybean genotypes in three planting dates.

\begin{tabular}{|c|c|c|c|c|c|c|c|c|}
\hline \multirow[t]{2}{*}{ Fechas de siembra } & \multicolumn{3}{|c|}{ Días a } & \multirow{2}{*}{$\begin{array}{c}\text { Altura de } \\
\text { planta }(\mathrm{cm})\end{array}$} & \multirow{2}{*}{$\begin{array}{c}\text { Altura de vainas } \\
\text { basales }(\mathrm{cm})\end{array}$} & \multirow{2}{*}{$\begin{array}{l}\text { Vainas/ } \\
\text { planta }\end{array}$} & \multirow{2}{*}{$\begin{array}{c}\text { Peso de } 100 \\
\text { sem. (gr) }\end{array}$} & \multirow{2}{*}{$\begin{array}{l}\text { Rend. } \\
\mathrm{kg} \mathrm{ha}^{-1}\end{array}$} \\
\hline & $\mathrm{R} 2$ & R5 & R7 & & & & & \\
\hline F. S 2. Jun. 05 & 51 & 81 & 114 & 60.4 & 7.6 & 63.9 & 12.3 & $1937.8 \mathrm{a}$ \\
\hline F. S. 3. Jun. 22 & 48 & 72 & 108 & 53.5 & 7.6 & 63.5 & 11.9 & $1864.9 \mathrm{a}$ \\
\hline F. S. 1. May. 19 & 60 & 93 & 128 & 55 & 6.8 & 61.1 & 12.4 & $1553.8 \mathrm{~b}$ \\
\hline Promedio & 53 & 82 & 117 & 56.3 & 7.3 & 62.8 & 12.2 & $1,785.50$ \\
\hline
\end{tabular}

*Medias con la misma letra no difieren estadísticamente (Tukey 0.05 ).

EnelCuadro3, se observan los valores medios de la interacción genotipo-fecha de siembra, las mejores combinaciones fueron: Cu04-139 con 2496.1 y $2442.9 \mathrm{~kg} \mathrm{ha}^{-1}$ en la primera y segunda fecha de siembra, seguida por Balbuena S-94, AG 6702 y AG 6301 con $2360.8,2261.3$ y $2247.5 \mathrm{~kg} \mathrm{ha}^{-1}$ en primera, tercera y segunda fecha de siembra respectivamente.

Los resultados sugieren considerar la ampliación del periodo de siembra durante mayo y junio, en lugar de la fecha de siembra actualmente recomendada del 01 al 20 de mayo; sin embargo, siembras posteriores al 15 de junio pueden verse afectadas por la ocurrencia de lluvias y presencia de maleza en las primeras etapas de desarrollo fenológico del cultivo, aunque ésta puede prevenirse sembrando en húmedo y si es necesario aplicando un herbicida en presiembra; pero también son más infestadas con MB (CEVAF, 2003; Cortez et al., 2005), como enseguida se detalla. be affected by the occurrence of rainfall and presence of weeds in early growth stage of crop development, although this can be prevented by sowing in wet and if necessary application of herbicide before planting; but also are more infested with whitefly (CEVAF, 2003; Cortez et al., 2005), as detailed soon.

\section{Response of soybean genotypes to whiteflies three planting dates}

In the first planting date was recorded the presence of whitefly from reduced to moderate, considering that chemical control is suggested when detecting an average of 15 adults per leaf (Cortezetal., 2005). As usual, the number of eggs was higher than any other stage of development, the number of first instar nymphs (N1) was higher than that of large nymphs (N4) and than adults, this due to mortality factors; however, 
Cuadro 3. Concentración de medias de rendimiento en la interacción genotipo-fecha de siembra, del estudio de 12 genotipos de soya en tres fechas de siembra.

Table 3. Concentration of means for yield in genotype-planting date interaction, of the study from 12 soybean genotypes in three planting dates.

\begin{tabular}{lcccc}
\hline Genotipo & $\begin{array}{c}\text { F. S. 1 } \\
(19 \text { de mayo })\end{array}$ & $\begin{array}{c}\text { F. S. 2 } \\
\text { (5 de junio })\end{array}$ & $\begin{array}{c}\text { F. S. 3 } \\
(22 \text { de junio })\end{array}$ & Media \\
\hline AG 5605 & $577.1(2)$ & $1.151 .3(2)$ & $1.493 .8(4)$ & 1.074 .00 \\
AG 5903 & $1.118 .8(2)$ & $1.784 .6(3)$ & $2.168 .8(2)$ & 1.690 .70 \\
AG 5905 & $1.064 .2(3)$ & $1.639 .2(1)$ & $1.368 .3(3)$ & 1.357 .20 \\
AG 6301 & $1.505 .8(3)$ & $\mathbf{2 . 2 4 7 . 5}(1)$ & $2.113 .3(2)$ & 1.955 .60 \\
AG 6702 & $1.512 .1(3)$ & $2.114 .6(2)$ & $\mathbf{2 . 2 6 1 . 3 ( 2 )}$ & 1.962 .60 \\
DB 6451 & $1.372 .5(5)$ & $1.954 .6(4)$ & $1.373 .3(6)$ & 1.566 .80 \\
Cajeme & $1.371 .3(1)$ & $1.707 .1(1)$ & $1.511 .7(1)$ & 1.530 .00 \\
Héctor & $1.977 .5(1)$ & $2.085 .4(1)$ & $2.032 .5(1)$ & 2.031 .80 \\
Balbuena S-94 & $\mathbf{2 . 3 6 0 . 8}(1)$ & $2.025 .8(1)$ & $1.776 .7(1)$ & 2.054 .40 \\
Hutcheson & $1.477 .5(1)$ & $2.069 .2(2)$ & $1.971 .3(2)$ & 1.839 .30 \\
Cu04-139 & $\mathbf{2 . 4 9 6 . 3 ( 1 )}$ & $\mathbf{2 . 4 4 2 . 9}(1)$ & $2.204 .2(1)$ & 2.381 .10 \\
Cu04-238 & $1.810 .8(1)$ & $2.031 .3(1)$ & $2.103 .8(1)$ & 1.981 .90 \\
Promedio & 1.553 .70 & 1.937 .80 & 1.864 .90 & 1.785 .50 \\
\hline
\end{tabular}

Los valores resaltados con negritas se ubican en el primer grupo de significancia, (Tukey 0.05 ).

\section{Respuesta de genotipos de soya a mosca blanca en tres fechas de siembra}

En la primera fecha de siembra se registró presencia de reducida a moderada de $\mathrm{MB}$, considerando que el control químico se sugiere cuando se detecta un promedio de 15 adultos por hoja (Cortez et al., 2005). Como es normal, el número de huevos fue mayor que cualquier otro estado de desarrollo, la cantidad de ninfas de primer instar (N1) fue mayor que la de ninfas grandes (N4) y que adultos, esto debido a los factores de mortalidad; sin embargo, la cantidad de adultos fue más elevada que la de N4, igual que en la segunda y tercera fecha de siembra(Figura 1 ) probablemente debido a las inmigraciones del insecto.

En la segunda fecha de siembra la presencia de adultos de MB fue más reducida que en la primera fecha, en ésta no alcanzó el promedio de cuatro especímenes por hoja (Figura $1 \mathrm{~B})$. El estado de desarrollo más abundante fue el de huevo, seguido por N1, adulto y N4. No obstante la cantidad de N1 y 4 no se diferenció mucho entre ambas fechas de siembra (Figuras 4-6).

En la tercera fecha de siembra el comportamiento de la MB en los genotipos evaluados fue homogéneo respecto a la primera y segunda fecha. En general las variedades mostraron una tendencia sostenida respecto a la incidencia del insecto; es decir, las variedades con mayor número de the number of adults was higher than $\mathrm{N} 4$, as in the second and third planting date (Figure 1) probably due to the migrations of the insect.

In the second planting date presence of adult whitefly was lower than in the first date, in this did not reach the average of four specimens per leaf (Figure 1B). The most abundant stage of development was egg, followed by N1, adult and N4. However the amount of N1 and N4 did not differ much between the two planting dates (Figures 4-6).

In the third planting date the behavior of whitefly in genotypes was homogeneous with respect to the first and second date. Overall, the varieties showed a sustained trend in the incidence of the insect; i.e. varieties with more adults were the ones with higher number of egg, N1 and N4 presented (Figure 1C). This probably was due to the increased pressure of selection to the response of the insect at various stages of development inspected in the genotypes. Again, as in the first and second planting date, the highest number of specimens was for egg, followed by N1, adult and N4 (Figures 3-6).

In the first planting date for each stage of development the ANOVA showed a significant difference between treatments $(p<0.001)$ (Table 4), the variety AG 5905 was the most infested (preferred) by adults of whitefly, but without differentiating from Hutcheson and AG 5605; in contrast 
adultos fueron las que mayor cantidad de huevo, N1 y N4 presentaron (Figura $1 \mathrm{C}$ ). Esto probablemente se debió a que se registró mayor presión de selección a la respuesta del insecto en las diferentes etapas de desarrollo inspeccionadas en los genotipos. Nuevamente, igual que en la primera y segunda fecha de siembra, la mayor cantidad de especímenes fue para huevo, seguida por N1, adulto y N4 (Figuras 3-6). to the variety Balbuena S-94 that was the least infested, without differentiating statistically from Hector, $\mathrm{Cu}$ 04-139 and $\mathrm{Cu} 04-238$.

For eggs the most infested variety was $\mathrm{Cu} 04-238$, without differing significantly from Cajeme, AG 5 905, DB 6451 , Hutcheson, AG 6301 and AG 6 702; in contrast varieties
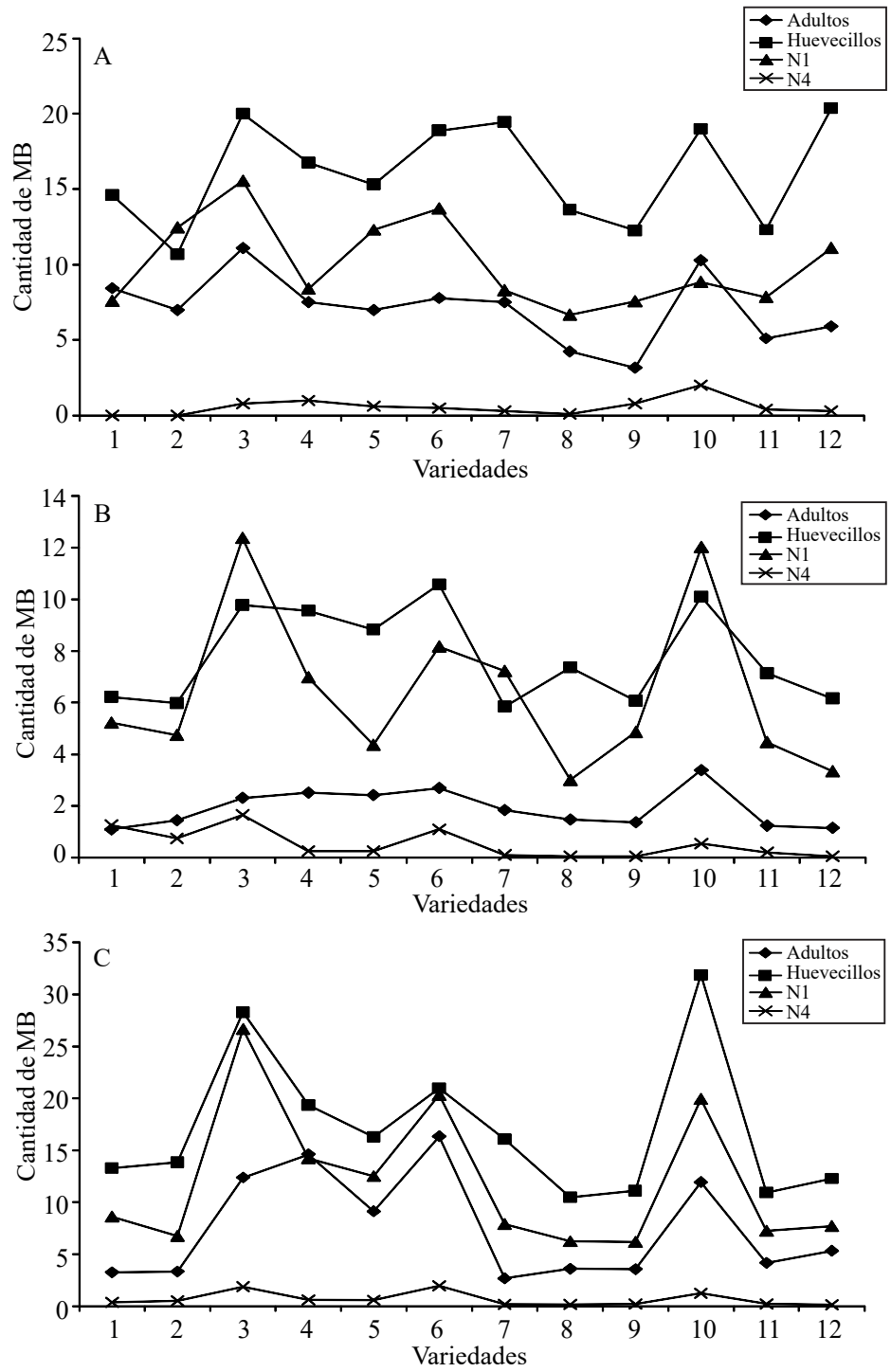

Figura 1. Número promedio de especimenes de mosca blanca por hoja en 12 variedades de soya. A) primera fecha de siembra; B) segunda fecha de siembra; y C) tercera fecha de siembra.

Figure 1. Average number of whitefly specimens per leaf in 12 soybean varieties. A) first planting date; B) second planting date; and C) third planting date.

En la primera fecha de siembra, para cada estado de desarrollo el ANVA mostró diferencia significativa entre tratamientos ( $p<0.001)$ (Cuadro 4); la variedad AG 5905 resultó la más infestada (preferida) por adultos de $\mathrm{MB}$, pero sin diferenciarse de Hutcheson y la AG 5605; en
AG 5 903, Balbuena S-94, Cu04-139, Hector, AG 5605 and AG 6702 were located the group of means with fewer eggs of whitefly. Most of N1 was recorded in cultivars AG 5 905, DB 6 451, AG 5903 and AG 6 702, while the lowest incidence occurred in Hector, Balbuena S-94, 
contraste la variedad Balbuena S-94 fue la menos infestada, sin diferenciarse estadísticamente de Héctor, Cu04-139 y $\mathrm{Cu} 04-238$.
AG 5 605, Cu04-139, Cajeme, Hutcheson and AG 6301. From the N4 stage of development, detected only in the last sampling, the highest number of specimens was

Cuadro 4. Número promedio de especímenes de mosca blanca en una hoja, en 12 variedades de soya. Primera fecha de siembra.

Table 4. Average number of whitefly specimens on a leaf, in 12 soybean varieties; first plating date.

\begin{tabular}{lcccc}
\hline Genotipos & Media adultos & Media huevos & Media N1 & Media N4 \\
\hline AG 5605 & $8.44 \mathrm{abc}^{*}$ & $14.62 \mathrm{bcde}$ & $7.63 \mathrm{de}$ & $0 \mathrm{~b}$ \\
AG 5903 & $6.99 \mathrm{cde}$ & $10.7 \mathrm{e}$ & $12.49 \mathrm{abc}$ & $0 \mathrm{~b}$ \\
AG 5905 & $11.11 \mathrm{a}$ & $20.04 \mathrm{ab}$ & $15.56 \mathrm{a}$ & $0.8 \mathrm{~b}$ \\
AG 6301 & $7.52 \mathrm{cde}$ & $16.78 \mathrm{abcd}$ & $8.39 \mathrm{cde}$ & $1.0 \mathrm{ab}$ \\
AG 6702 & $6.98 \mathrm{cde}$ & $15.33 \mathrm{abcde}$ & $12.32 \mathrm{abc}$ & $0.6 \mathrm{~b}$ \\
DB 6451 & $7.78 \mathrm{bcd}$ & $18.89 \mathrm{abc}$ & $13.71 \mathrm{ab}$ & $0.5 \mathrm{~b}$ \\
Cajéme & $7.52 \mathrm{bcd}$ & $19.47 \mathrm{ab}$ & $8.34 \mathrm{cde}$ & $0.3 \mathrm{~b}$ \\
Héctor & $4.25 \mathrm{ef}$ & $13.64 \mathrm{cde}$ & $6.69 \mathrm{e}$ & $0.1 \mathrm{~b}$ \\
Balbuena S-94 & $3.15 \mathrm{f}$ & $12.29 \mathrm{de}$ & $7.57 \mathrm{de}$ & $0.8 \mathrm{~b}$ \\
Hutcheson & $10.3 \mathrm{ab}$ & $19.01 \mathrm{abc}$ & $8.86 \mathrm{cde}$ & $2.0 \mathrm{a}$ \\
CU 04-139 & $5.11 \mathrm{def}$ & $12.32 \mathrm{de}$ & $7.86 \mathrm{de}$ & $0.4 \mathrm{~b}$ \\
CU 04-238 & $5.91 \mathrm{cdef}$ & $20.37 \mathrm{a}$ & $11.11 \mathrm{bcd}$ & $0.3 \mathrm{~b}$ \\
Promedio & 7.08 & 16.12 & 10.04 & 0.6
\end{tabular}

*Medias con la misma letra no difieren estadísticamente (Tukey 0.05).

Para huevos la variedad más infestada fue $\mathrm{Cu} 04-238$, sin diferenciarse significativamente de Cajéme, AG 5905, DB 6451, Hutcheson, AG 6301 y AG 6702; en contraste las variedades AG 5903, Balbuena S-94, Cu04-139, Héctor, AG 5605 y AG 6702 se ubicaron en el grupo de medias con menor cantidad de huevos de MB. La mayor cantidad de N1 se registró en los cultivares AG 5905, DB 6451, AG 5903 y AG 6702, mientras que la menor incidencia ocurrió en Héctor, Balbuena S-94, AG 5605, Cu04-139, Cajéme, Hutcheson y AG 6301. Del estado de desarrollo N4, detectado sólo en el último muestreo realizado, la más elevada cantidad de especímenes se presentó en las variedades Hutcheson y AG 6301; con menor abundancia el resto de las variedades se ubicaron en el mismo grupo de medias.

En la segunda fecha de siembra la variedad Hutcheson mostró una significativa $(p<0.001)$ mayor cantidad de adultos de MB, sin diferenciarse de AG 6301, DB 6451 y AG 6702 (Cuadro 5); la menor presencia de adultos se observó en AG 5605, 11 Cu04-139 y 12 Cu04-238. DB 6451 mostró la mayor cantidad de huevo y Cajéme la menor cantidad. Respecto a la etapa de desarrollo N1, las variedades AG 5905 y Hutcheson sobresalieron con la mayor cantidad de ejemplares, aunque ésta última no se diferenció de DB 6451. in varieties Hutcheson and AG 6 301; with lower abundance the rest of the varieties were in the same group of means.

In the second planting date Hutcheson variety showed a significant difference $(p<0.001)$ higher number of adults, not differentiated from AG 6 301, DB 6451 and AG 6702 (Table 5); the less presence of adults was observed inAG 5605, $11 \mathrm{Cu} 04-139$ and $12 \mathrm{Cu} 04-238$. DB 6451 showed the highest amount of egg and Cajeme the lowest. Regarding N1 stage of development, Hutcheson andAG 5905 varieties excelled with the largest number of specimens, although the latter did not differ from DB 6451. Varieties with lower average number of N1/leaf was Hector, without differentiating from Cu04-238, AG 6702,AG 5 903, Balbuena S-94, Cu04-139 andAG 5605 varieties. Finally, N4 stage was the most abundant in varieties AG 5905,AG 5605 and AG 6702 and the rest of the varieties showed less presence, without differentiating statistically. In all ANOVA detected highly significant statistical difference between treatments $(p<0.001)$.

On the last planting date the highest amount of adults occurred in DB 6451 and AG $6301(p<0.001)$; the less infested varieties were seven of the 12 evaluated, in lesser 
Las variedades con menor número promedio de N1/hoja fue Héctor, sindiferenciarse de las variedades Cu04-238, AG6702, AG 5903, Balbuena S-94, Cu04-139y AG 5605. Finalmente, la etapa N4 fue más abundante en las variedades AG 5905, AG 5605 y AG 6702 y el resto de variedades mostraron menor presencia, sin diferenciarse estadísticamente. En todos los ANVAse detectó diferencia estadística altamente significativa entre tratamientos $(p<0.001)$. extent Cajeme (Table 6). The highest amount of egg occurred in Hutcheson and AG 5905; varieties Hector, Balbuena S 94, Cu04-139 and $\mathrm{Cu} 04-238$ had the lowest amount, without differentiating from AG 5 605, AG 5903 , Cajeme and AG 6702 . N1 were the most abundant in the variety AG 5905, followed in different group of means by DB 6451 and Hutcheson; with lower incidence varieties Hector, Balbuena S 94, AG 5 903, Cu04-139, Cu04-238,

Cuadro 5. Número promedio de especímenes de mosca blanca en una hoja, en 12 variedades de soya. Segunda fecha de siembra.

Table 5. Average number of whitefly specimens on a leaf, in 12 soybean varieties; second planting date.

\begin{tabular}{lcccc}
\hline Variedades & Media adultos & Media huevos & Media N1 & Media N4 \\
\hline AG 5605 & $1.11 \mathrm{e}^{*}$ & $6.22 \mathrm{c}$ & $5.22 \mathrm{cde}$ & $1.25 \mathrm{ab}$ \\
AG 5903 & $1.46 \mathrm{cde}$ & $5.99 \mathrm{c}$ & $4.75 \mathrm{cde}$ & $0.75 \mathrm{bc}$ \\
AG 5905 & $2.32 \mathrm{bcd}$ & $9.79 \mathrm{ab}$ & $12.37 \mathrm{a}$ & $1.65 \mathrm{a}$ \\
AG 6301 & $2.53 \mathrm{ab}$ & $9.56 \mathrm{ab}$ & $6.99 \mathrm{~cd}$ & $0.25 \mathrm{c}$ \\
AG 6702 & $2.42 \mathrm{abc}$ & $8.84 \mathrm{abc}$ & $4.36 \mathrm{cde}$ & $0.25 \mathrm{c}$ \\
DB 6451 & $2.69 \mathrm{ab}$ & $10.56 \mathrm{a}$ & $8.16 \mathrm{bc}$ & $1.10 \mathrm{ab}$ \\
Cajéme & $1.85 \mathrm{bcd}$ & $5.84 \mathrm{c}$ & $7.24 \mathrm{~cd}$ & $0.10 \mathrm{c}$ \\
Héctor & $1.49 \mathrm{cde}$ & $7.36 \mathrm{abc}$ & $3.01 \mathrm{e}$ & $0.05 \mathrm{c}$ \\
Balbuena S-94 & $1.37 \mathrm{de}$ & $6.09 \mathrm{c}$ & $4.86 \mathrm{cde}$ & $0.05 \mathrm{c}$ \\
Hutcheson & $3.41 \mathrm{a}$ & $10.1 \mathrm{ab}$ & $12.02 \mathrm{ab}$ & $0.55 \mathrm{bc}$ \\
Cu04-139 & $1.26 \mathrm{e}$ & $7.16 \mathrm{bc}$ & $4.47 \mathrm{cde}$ & $0.20 \mathrm{c}$ \\
Cu04-238 & $1.16 \mathrm{e}$ & $6.15 \mathrm{c}$ & $3.34 \mathrm{de}$ & $0.05 \mathrm{c}$ \\
Promedio & 1.92 & 7.80 & 6.39 & 0.52 \\
\hline
\end{tabular}

* Medias con la misma letra no difieren estadísticamente (Tukey 0.05).

En la última fecha de siembra la mayor cantidad de adultos de MB ocurrió en DB 6451 y AG 6301( $p<0.001)$; las variedades menos infestadas fueron siete de las 12 evaluadas, en menor grado Cajéme (Cuadro 6). La mayor cantidad de huevo ocurrió en las variedades Hutcheson y AG 5905; las variedades Héctor, Balbuena S 94, Cu04-139 y Cu04-238 se observó la menor cantidad, sin diferenciarse de AG 5605, AG 5903, Cajéme y AG 6702. Las N1 fueron más abundantes en la variedad AG 5905, seguida en diferente grupo de medias por DB 6451y Hutcheson; con menor incidencia fueron las variedades Héctor, Balbuena S 94, AG 5903 AG 5903, Cu04-139, Cu04-238, Cajéme y AG 5605. Finalmente el mayor número de $\mathrm{N} 4$ la registraron las variedades DB 6451, AG 5905 y Hutcheson; el resto de los cultivares, en primer lugar Cu04-238, mostraron la cantidad más reducida de especímenes de esta etapa de desarrollo.
Cajeme and AG 5 605. Finally the highest number of N4 was registered by varieties DB 6 451, AG 5905 and Hutcheson; the rest of the cultivars, in first place $\mathrm{Cu} 04-238$, showed the lowest number of specimens from this stage of development.

The amount of whitefly (egg, N1, N4 and adults), through the phenological development of the crop and total, was generally higher in the third planting date and the first date showed higher populations of insect regarding the second planting date, which is shown in the average of individuals per stage of development sampled from each planting date (Table 4, 5 and 6).

The reduced presence of whitefly in the first samples made from the second planting date, during the critical stage of damage, caused by the occurrence of rainfall 
Cuadro 6. Número promedio de especímenes de mosca blanca en una hoja, en 12 variedades de soya. Tercera fecha de siembra.

Table 6. Average number of whitefly specimens on a leaf, in 12 soybean varieties; third planting date.

\begin{tabular}{lcccc}
\hline Variedades & Media adultos & Media huevos & Media N1 & Media N4 \\
\hline AG 5605 & $3.25 \mathrm{~d}^{*}$ & $13.28 \mathrm{~cd}$ & $8.6 \mathrm{de}$ & $0.36 \mathrm{c}$ \\
AG 5903 & $3.33 \mathrm{~d}$ & $13.87 \mathrm{~cd}$ & $6.74 \mathrm{e}$ & $0.50 \mathrm{c}$ \\
AG 5905 & $12.38 \mathrm{bc}$ & $28.3 \mathrm{a}$ & $26.67 \mathrm{a}$ & $1.86 \mathrm{a}$ \\
AG 6301 & $14.62 \mathrm{ab}$ & $19.34 \mathrm{bc}$ & $14.21 \mathrm{c}$ & $0.6 \mathrm{bc}$ \\
AG 6702 & $9.15 \mathrm{c}$ & $16.25 \mathrm{bcd}$ & $12.5 \mathrm{~cd}$ & $0.58 \mathrm{bc}$ \\
DB 6451 & $16.36 \mathrm{a}$ & $20.97 \mathrm{~b}$ & $20.3 \mathrm{~b}$ & $1.94 \mathrm{a}$ \\
Cajéme & $2.7 \mathrm{~d}$ & $16.06 \mathrm{bcd}$ & $7.87 \mathrm{e}$ & $0.16 \mathrm{c}$ \\
Héctor & $3.64 \mathrm{~d}$ & $10.49 \mathrm{~d}$ & $6.22 \mathrm{e}$ & $0.14 \mathrm{c}$ \\
Balbuena S-94 & $3.57 \mathrm{~d}$ & $11.12 \mathrm{~d}$ & $6.17 \mathrm{e}$ & $0.18 \mathrm{c}$ \\
Hutcheson & $11.96 \mathrm{bc}$ & $31.88 \mathrm{a}$ & $19.91 \mathrm{~b}$ & $1.24 \mathrm{ab}$ \\
Cu04-139 & $4.19 \mathrm{~d}$ & $10.92 \mathrm{~d}$ & $7.23 \mathrm{e}$ & $0.22 \mathrm{c}$ \\
Cu04-238 & $5.37 \mathrm{~d}$ & $12.28 \mathrm{~d}$ & $7.68 \mathrm{e}$ & $0.12 \mathrm{c}$ \\
Promedio & 7.54 & 17.06 & 12.00 & 0.65 \\
\hline
\end{tabular}

* Medias con la misma letra no difieren estadísticamente (Tukey 0.05).

La cantidad de MB (huevo, N1, adultos y N4), a través del desarrollo fenológico del cultivo y total, fue generalmente mayor en la tercera fecha de siembra y la primera fecha mostró mayores poblaciones del insecto respecto a la segunda fecha de siembra, lo que se muestra en el promedio de individuos por etapa de desarrollo muestreada, de cada fecha de siembra (Cuadro 4, 5 y 6).

La reducida presencia de $\mathrm{MB}$ en los primeros muestreos realizados en la segunda fecha de siembra, durante la etapa crítica de daño, fue provocada por la ocurrencia de lluvias (Hilje y Morales, 2008), mayores en esta fecha de siembra que en la fecha uno, en la que se presentaron cuando el cultivo estaba próximo a la madurez fisiológica, cuando la presencia natural del insecto se reduce en forma natural porque el follaje es poco suculento (López, 1996a). La primera fecha registró cuatro lluvias importantes en el periodo próximo a la madurez fisiológica, de 20.4, 26.0,21.4 y $45.2 \mathrm{~mm}$; en la segunda fecha también ocurrieron cuatro precipitaciones, de 21.4, 45.2, 37.6 y $31.8 \mathrm{~mm}$, pero fueron más abundantes y se registraron cuando el cultivo estaba suculentoy apto para la alimentación, y colonización de MB; finalmente, la tercera fecha recibió sólo dos lluvias de 37.6 y $31.8 \mathrm{~mm}$, antes del inicio de la etapa crítica de daño de la MB(López, 1996a; Martínez et al., 1998).

En algunos genotipos, algunas etapas de desarrollo del insecto tuvieron presencia abundante y después se redujo, probablemente debido a que algunas variedades poseen
(Hilje and Morales, 2008), higher in this planting date than date one, in which occurred when the crop was close to physiological maturity, when the natural presence of the insect decreases naturally because foliage is less succulent (López, 1996a). The first date recorded four significant rainfall in the period near to physiological maturity of 20.4, 26.0, 21.4 and $45.2 \mathrm{~mm}$; in the second date also occurred four precipitation, $21.4,45.2,37.6$ and $31.8 \mathrm{~mm}$, but were more abundant and recorded when the crop was succulent and suitable for feeding, and colonization of whitefly; finally, the third date received two rains of 37.6 and $31.8 \mathrm{~mm}$, before the start of the critical stage of damage from whitefly (López, 1996a; Martínez et al., 1998).

In some genotypes, some stages of development of the insect had abundant presence and then reduced, presumably because some varieties have an antibiotic effect (Kogan, 1990), so although recorded high number of adults and eggs, pupa in late stage of developments do not thrive in the same proportion. In this sense, the variety Hector characterized as "resistant" to whitefly (Martínez et al., 1998), for the low preference of the insect (antixenosis) (Kogan, 1990), a feature shared in part by Cajeme and Balbuena S-94; in contrast Hutcheson variety is known as one of the most preferred materials by whitefly in Sinaloa (Cortez et al., 2003), is unknown the factor involved in the no preference of whitefly towards these materials; however, is considered that is due to the reduced density 
un efecto antibiótico (Kogan, 1990), por lo que aunque se registre elevada cantidad de adultos y huevos, los inmaduros de etapas de desarrollo posterior no prosperan en la misma proporción. En este sentido, la variedad Héctor caracterizada como "resistente" a MB (Martínez et al., 1998), por la poca preferencia del insecto (antixenosis) (Kogan, 1990), rasgo compartido en parte por Cajéme y Balbuena S-94; en contraste la variedad Hutcheson es conocida como uno de los materiales más preferidos por MB en el estado de Sinaloa (Cortez et al.,2003), se desconoce el factor involucrado en la no preferencia de MB hacia estos materiales; sin embargo, se considera que es debida a la reducida densidad de tricomas en el envés de las hojas, como se reporta en diferentes cultivos (Inbar y Gerling, 2008; Taggar y Hill, 2012).

Enlas tres fechas de siembra evaluadas la presencia de MB fue reducida provocando datos de infestación poco homogéneos, por ejemplo en la primera fecha de siembra la variedad AG 5605 se ubicó en el grupo de medias más infestadas, mientras que en la segunda y tercera fecha de siembra se ubicó en el grupo menos infestado. En la tercera fecha de siembra la abundancia de MB fue ligeramente superior, mostrandomayor estabilidad en la respuesta de los genotipos.

Enresumen, los materiales más preferidos por adultos de MBy mayormente infestados por sus inmaduros fueron Hutcheson, DB 6451, AG 5905 y AG 6301. En contraparte las variedades menos preferidas y menos infestadas fueron Héctor, $\mathrm{Cu} 04$ 238, Balbuena S-94, Cajémey AG 5903, el resto mostraron un comportamiento intermedio y menos consistente: variedades Cu04-139, AG 5605 y AG 6702.

En primer instancia la variable que determinará la selección y eventual recomendación para empleo de una variedad, será el rendimiento, en combinación con la adecuada respuesta a MB (Cortez et al., 2003; Cortez et al., 2005), que posean preferentemente el mecanismo de resistencia por antixenosis (Kogan, 1990), para que la reproducción del insecto seamenor y sus poblaciones no emigren en elevadas cantidades afectando posteriormente a cultivos hospederos preferidos como tomate y cucurbitáceas en general, que se constituyen como cultivos de alto valor económico fuentes de empleo y generadores de divisas extranjeras en el estado (Áviles et al., 2004).

Esnecesario continuar con estudios que permitan incrementar la cantidad de genotipos con alguna característica de resistencia a MB en soya, ya que el empleo de una variedad resistente en una región agrícola, eventualmente será dañada por MB al no tener más opciones de alimentación of trichomes on the underside of the leaves, as reported in different crops (Inbar and Gerling, 2008; Taggart and Hill, 2012).

In the three planting dates the presence of whitefly was reduced inducing inhomogeneous infestation data, for example on the first planting variety AG 5605 was located in the infested group of means while in the second and third planting date was located in the less infested group of means. In the third planting date the abundance of whitefly was slightly higher, showing higher stability in the response of genotype.

In summary, the most preferred materials for whitefly adults and highly infested by its pupa were Hutcheson, DB 6451,AG 5905 and AG 6301 . In contrast less preferred varieties and less infested were Hector, Cu04-238, Balbuena S-94, Cajeme and AG 5903 , the rest showed an intermediate behavior and less consistent: varieties Cu04-139, AG 5605 and AG 6702.

In first instance the variable that will determine selection and eventual recommendation for use of a variety, will be yield, in combination with an appropriate response to whitefly (Cortez et al., 2003; Cortez et al., 2005), preferably having the resistance mechanism of antixenosis (Kogan, 1990), so the reproduction of the insect is smaller and its populations does not migrate in large quantities subsequently affecting to preferred host crops such as tomatoes and cucurbitaceous in general, which are constituted as crops of high economic value, sources of employment and generators of foreign exchange in the state (Áviles et al., 2004).

It is necessary to continue studies to increase the amount of genotypes with some resistance traits to whitefly in soybeans, since the use of a resistant variety in an agricultural region, eventually will be damaged by whitefly by not having more options of food (Brier, 2003). In this sense, it is recommended to propose the release of Cu04-139 and $\mathrm{Cu} 04-$ 238 as new commercial varieties of soybeans for Sinaloa.

\section{Conclusions}

Variables days to flowering, days to seed formation, days to physiological maturity, plant height and yield for 12 genotypes and three planting dates and their interaction were obtain. The experimental line $\mathrm{Cu} 04-139$ was superior in yield to other genotypes, with $2381.1 \mathrm{~kg} \mathrm{ha}^{-1}$, followed by Balbuena S-94, Hector, Cu04-238, AG 6 702, AG 6301 and 
(Brier, 2003). En éste sentido, se recomienda proponer la liberación de Cu04-139y Cu04-238 comonuevas variedades comerciales de soya para Sinaloa.

\section{Conclusiones}

Se obtuvieron las variables días a floración, días a formación de grano, días a madurez fisiológica, altura de planta y rendimiento, para 12 genotipos y tres fechas de siembra, y su interacción. La línea experimental Cu04-139 resultó superior en rendimiento al resto de los genotipos, con $2381.1 \mathrm{~kg} \mathrm{ha}^{-1}$, enseguida se ubicaron Balbuena S-94, Héctor, Cu04-238, AG 6702, AG 6301 y Hutcheson con 2 054.4; $2031.8 ; 1981.9 ; 1962.6 ; 1955.6$ y $1839.3 \mathrm{~kg} \mathrm{ha}^{-1}$ respectivamente. La mejor fecha de siembra con relación a rendimiento fue la segunda (junio 5), seguida por la tercera (junio 22) con un rendimiento medio de 1937.8 y 1864.9 $\mathrm{kg} \mathrm{ha}^{-1}$. Las mejores combinaciones genotipo-fecha de siembra fueron Cu04-139 con 2496.1 y $2442.9 \mathrm{~kg} \mathrm{ha}^{-1} \mathrm{en}$ la fecha de siembra 1 y 2, Balbuena S-94, AG 6702 y AG 6301 con $2360.8 ; 2261.3$ y $2247.5 \mathrm{~kg} \mathrm{ha}^{-1}$ en las fechas 1,3 y 2 respectivamente. Los materiales preferidos por adultos de mosca blanca y mayormente infestados por sus inmaduros fueron Hutcheson, DB 6451, AG 5905 y AG 6301. Las variedades menos preferidas y menos infestadas por mosca blanca fueron Héctor, Cu04-238, Balbuena S-94, Cajeme y AG 5903. Los genotipos con mejor rendimiento y mejor respuesta a mosca blanca, menos y moderadamente preferidas, fueron Cu04-139, Cu04-238 y AG 6702, y pueden ser eventualmente consideradas para siembra comercial en el norte de Sinaloa.

\section{Literatura citada}

Avilés, G. M. C.; U. Nava, C. J. A.; Garzón, T. de J.; Wong, P. y Pérez, V. J. J. 2004. Manejo integrado de la mosquita blanca Bemisia sp., en tomate para consumo fresco. INIFAP-CIRNO. Campo Experimental Valle de Culiacán. Folleto técnico Núm. 28. Culiacán, Sinaloa, México. 76 p.

Baigorri, H. 2002. Conclusiones sobre el efecto de la fecha de siembra en el desarrollo y crecimiento de los cultivos. In: manejo del cultivo de la soja en Argentina.Actualizaciones. (Ed.) Baigorri, H. y Juárez, M. 100-111 pp.

Brier, H.; De Barro, P.; Wood, N. and Mills, G. 2003. Potential impact of silverleaf whitefly (Bemisia tabaci type B) on the Australian soybean industry and possible management strategies. In $12^{\text {th }}$ Australian Soybean Conference. Toowoomba, Australia. 7 p.
Hutcheson with 2 054.4, 2 031.8, 1 981.9, $1962.6,1955.6$ and $1839.3 \mathrm{~kg} \mathrm{ha}^{-1}$ respectively. The best planting date regarding yield was the second (June 5), followed by the third (June 22) with an average yield of 1937.8 and 1864.9 $\mathrm{kg} \mathrm{ha}^{-1}$. The best combinations genotype-planting date were Cu04-139 with 2496.1 and $2442.9 \mathrm{~kg} \mathrm{ha}^{-1}$ in planting date 1 and 2, Balbuena S-94,AG 6702 and AG 6301 with 2360.8, 2261.3 and $2247.5 \mathrm{~kg} \mathrm{ha}^{-1}$ on dates 1,3 and 2 respectively. Preferred materials by adults and highly infested by their pupa were Hutcheson, DB 6 451, AG 5905 and AG 6301. The less preferred and less infested varieties with whiteflies were Hector, Cu04-238, Balbuena S-94, Cajeme and AG 5 903. The genotypes with best yield and better response to whitefly less and moderately preferred, were Cu04- 139, Cu04-238 and AG 6702, and eventually may be considered for commercial planting in northern Sinaloa.

End of the English version

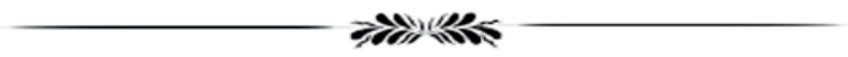

Campo Experimental Valle del Fuerte (CEVAF). 2003. Guía para la asistencia técnica agrícola para el área de influencia del campo. Experimental Valle del Fuerte. INIFAP-CIRNO. Campo Experimental Valle del Fuerte. Agenda técnica. $6^{\mathrm{a}}$ Edición. Juan José Ríos, Sinaloa, México. 208 p.

Cortez, M. E.; Macías, C. J. y Rodríguez, C. F. G. 2003. No preferencia y antibiósis de cultivares de soya a la mosquita blanca de la hoja plateada Bemisia argentifolii (Hemiptera: Aleyrodidae) en el norte de Sinaloa. In: memorias VII Congreso Internacional en Ciencias Agrícolas. UABC. Instituto de Ciencias Agrícolas. Mexicali, B. C. 374-378 pp.

Cortez, M. E.; Rodríguez, C. F. G.; Martínez, C. J. L. y Macías, C. J. 2005. Tecnología de producción y manejo de la mosca blanca de la hoja plateada en el cultivo de soya en el norte de Sinaloa. INIFAP-CIRNO. Campo Experimental Valle del Fuerte. Folleto técnico Núm. 25. Los Mochis, Sinaloa, México. 52 p.

Ellsworth, P.; Diehl, J.; Dennehy, T. and Naranjo, S. 1994. Sampling sweetpotato whiteflies in cotton. University of Arizona. IPM series number 2. Tucson, Arizona. 2 p.

Fehr, W.; Caviness, C.; Burmood, D. and Pennington, J. 1971. Stage of development descriptions for soybeans, Glycine max (L.) Merrill. Crop Sci.11(6):929-931.

Flint, M. L. and Gouveia, P. 2001. IPM in practice: principles and methods of integrated pest management. University of California Press. Oakland, CA. 116-117 pp.

Hilje, L. and Morales, F. J. 2008. Whitefly bioecology and management in Latin America. In: Capinera, J. (Ed.). Encyclopedia of entomology. Springer. 4250-4260 p.

Inbar, M. and Gerling, D. 2008. Plant-mediated interactions between whiteflies, herbivores, and natural enemies. Annu. Rev Entomol 53:431-448.

Kogan, M. 1990. Resistencia de la planta en el manejode Plagas.In: Metcalf, R. L y Luckman, W. H. (Comps.). Introducción al manejo de plagas de insectos. Trad. al español, García, T, A. y Elizondo, M. R. 2a (Ed.). Limusa, S. A. de C. V. México, D. F. 123-172 pp. 
López, A. B. 1996a. Periodos de protección en soya contra la mosquita blanca de la hoja plateada (Bemisia argentifolii Bellows \& Perring), en el Valle del Fuerte, Sin. In: mosquita blanca en el Noroeste de México, 1995. INIFAP-CIRNO. Memoria científica Núm. 3. Cd. Obregón Sonora. 24-25 pp.

López, A. B. 1996b. Hospedantes de la mosquita blanca (Bemisia spp.), en el Valle del Fuerte, Sinaloa. 1994. In: mosquita blanca en el Noroeste de México, 1996. INIFAP-CIRNO. Memoria científica Núm. 2. Cd. Obregón Sonora. 38-39 pp.

Martínez, C. J. L.; Rodríguez, C. F.; Navarro, S. J. y López, A. B. 1998. Establecimiento de un manejo integrado para la mosquita blanca en soya en el Norte de Sinaloa. Talleres gráficos del CEVAF. Juan José Ríos, Sinaloa, México. Folleto técnico Núm. 14. ISSN-1405-597X. 16 p.
Ruíz, C. J.A.; Medina, G. G.; Macías, C. J.; Silva, S. M. M.y Díaz, P. G. 2005. Estadísticas climatológicas básicas del estado de Sinaloa (periodo 1961-2003). Librotécnico Núm. 2. SAGARPA-Instituto Nacional de Investigaciones Forestales, Agrícolas y Pecuarias (INIFAP). Prometeo Editores, S. A de C. V. Guadalajara, Jalisco. 151 p.

Statistical Analysis System (SAS) Institute. SAS Institute. 2010. SAS systems for information delivery for Windows. Release 9.2. Cary, North Caroline. USA. 16 p.

Servicio Nacional de Inspección y Certificación de Semillas (SNICS). 2011. Registro de variedades vegetales. SNICS-SAGARPA. http:// snics.sagarpa.gob.mx/dov/páginas/default.aspx. (consultado marzo, 2012).

Taggar, G. K. and Hill, R. S. 2012. Preference of whitefly, Bemisia tabaci, towards black gram genotypes: Role of morphological leaf characteristics. Phytoparasitica. 40(5):461-474. 